\title{
Impactos socioambientais: a percepção de uma comunidade ribeirinha do Baixo Amazonas, Pará, Brasil
}

\author{
Marcelia Castro Cardoso ${ }^{1^{*}}$ (D), Helionora da Silva Alves ${ }^{2}$ (D), Thiago Almeida Vieira ${ }^{3}$ \\ ${ }^{1}$ Programa de Pós-Graduação em Sociedade, Natureza e Desenvolvimento (PPGSND), Universidade Federal do Oeste \\ do Pará, Bairro do Salé, CEP 68135-110, Santarém, PA; Secretaria Municipal de Educação do Município de Monte \\ Alegre, PA. \\ ${ }^{2}$ Universidade Federal do Oeste do Pará, Instituto de Biodiversidade e Florestas(IBEF); Programa de Pós-Graduação \\ em Sociedade, Ambiente e Qualidade de Vida, Campus Santarém, Unidade Tapajós, Av. Vera Paz, s/n., CEP 68035-110, \\ Santarém, PA; \\ ${ }^{3}$ Universidade Federal do Oeste do Pará, Instituto de Biodiversidade e Florestas(IBEF); Programa de Pós-Graduação \\ em Sociedade, Ambiente e Qualidade de Vida (PPGSAQ) e Programa de Pós-Graduação em Sociedade, Natureza e \\ Desenvolvimento (PPGSND), Campus Santarém, Unidade Tapajós, Av. Vera Paz, s/n., CEP 68035-110, Santarém, PA. \\ * Autora para correspondência: marce.liah007@gmail.com
}

Recebido em 03 de outubro de 2020.

Aceito em 07 de dezembro de 2020.

Publicado em 31 de dezembro de 2020.

Resumo - O objetivo deste trabalho foi realizar uma caracterização socioeconomica e identificar os principais impactos socioambientais a partir da percepção de moradores e pescadores artesanais locais de uma comunidade ribeirinha que vive no entorno do Lago do Juá, localizado em Santarém, Pará, Brasil. Para isso, realizou-se entrevistas semiestruturadas com informantes-chave e os dados foram submetidos a análise descritiva dos elementos textuais. Segundo os entrevistados, entre os anos de 1950 e 2000, o lago foi restrito ao turismo, ao lazer e as pesca de subsistência. Mas, com o processo de expansão urbana, o mesmo tem sofrido impactos como desmatamento, assoreamento, alteração da qualidade da água, entre outros. A maioria dos entrevistados informou que a retirada da cobertura vegetal impactou diretamente no lago, causando alterações nos aspectos estéticos da água, além da redução na disponibilidade de peixes. Informaram ainda, que os empreendimentos imobiliários e as ocupações desordenadas nas adjacências contribuíram para degradação do lago, além de afetarem na perda de tranquilidade da comunidade. Portanto, entende-se que o Lago do Juá é constituído por complexas relações socioambientais e a ineficácia das políticas públicas têm contribuído para que processos contínuos de ocupação e uso causem modificações abruptas dos espaços naturais.

Palavras-chave: Relações Socioambientais; Políticas Públicas; Amazônia.

\section{Environmental impacts: the perception of a ribeirinha community of Lower Amazonas, Pará, Brazil}

Abstract - The objective of this study was to perform a socioeconomic characterization and identify the main socio-environmental impacts from the perception of local residents and artisanal fishermen from a riverside community that lives around Lago do Juá, located in Santarém, Pará, Brazil. For this, semi-structured interviews were conducted with key informants and the data were subjected to descriptive analysis of the textual elements. According to respondents, between the years 1950 and 2000, the uses of the lake were restricted to tourism, leisure and subsistence fishing. However, with 
the urban expansion process, it has suffered impacts such as deforestation, silting, alteration of water quality, among others. Most respondents reported that the removal of the vegetation cover directly impacted the lake, causing changes in the aesthetic aspects of the water, in addition to a reduction in the availability of fish. They also reported that real estate developments and disorderly occupations in the surrounding areas contributed to the degradation of the lake, in addition to causing loss of tranquility in the community. Therefore, it is understood that Lago do Juá is constituted by complex socio-environmental relations and the ineffectiveness of public policies has contributed to the continuous processes of occupation and use that cause abrupt changes in natural spaces.

Keywords: Social and Environmental Relations; Public Policies; Amazon.

\section{Impactos socioambientales: la percepción de una comunidad ribereña del Baixo Amazonas, Pará, Brasil}

Resumen - El objetivo de este estudio fue realizar una caracterización socioeconómica e identificar los principales impactos socioambientales a partir de la percepción de los habitantes y pescadores artesanales locales de una comunidad ribereña que vive alrededor del Lago do Juá, ubicado en Santarém, Pará, Brasil. Para ello, se realizaron entrevistas semiestructuradas con informantes clave y los datos fueron sometidos a un análisis descriptivo de los elementos textuales. Según los encuestados, entre los años 1950 y 2000, la laguna estuvo restringida al turismo, el ocio y la pesca de subsistencia. Sin embargo, con el proceso de expansión urbana ha sufrido impactos como deforestación, sedimentación, alteración de la calidad del agua, entre otros. Una gran parte de los encuestados informó que la eliminación de la cubierta vegetal afectó directamente a la laguna, provocando cambios en los aspectos estéticos del agua, además de reducir la disponibilidad de peces. Asimismo, informaron que los desarrollos inmobiliarios y ocupaciones desordenadas en las áreas aledañas contribuyeron a la degradación de la laguna, además de afectar la pérdida de tranquilidad en la comunidad. Por lo tanto, se entiende que el Lago do Juá está constituido por relaciones socioambientales complejas y la ineficacia de las políticas públicas ha contribuido a que los procesos continuos de ocupación y uso resulten en cambios bruscos en espacios naturales.

Palabras clave: Relaciones socioambientales; Políticas públicas; Amazonía.

\section{Introdução}

No processo histórico de ocupação da Amazônia brasileira, a partir da década de 60, grandes projetos foram instalados, no intuito de promover o desenvolvimento, o que acarretou em diversas problemáticas na região, por não serem consideradas as extensas áreas territoriais, a diversidade ambiental e cultural (Oliveira e Carleial 2013).

Esse modelo de desenvolvimento adotado gerou, ao longo de décadas, impactos à biodiversidade e às sociedades locais da região, por não considerarem que a Amazônia não é uma região homogênea, assim como, em seu contexto urbano que também é rico em sociobiodiversidade (Trindade Júnior 2015). O autor discute ainda sobre a tendência da urbanização no espaço amazônico, que sinaliza para um outro tipo de urbanidade, no qual a vida cotidiana presente nas cidades amazônicas "oferece possibilidades e potencialidades não só para avaliar a natureza da urbanização em curso, como também para pensar "cidades para a floresta", menos formatadas a padrões externos e menos comprometidas com um modelo único de vida e de valores urbanos" (Trindade Júnior 2015, p. 104). 
Para Becker (2009), na Amazônia brasileira, as políticas públicas estão pautadas em duas óticas: 1) políticas públicas direcionadas ao incentivo e o favorecimento de instalações de infraestrutura que visem o desenvolvimento econômico, ou seja, reguladas pela racionalidade econômica; e 2) políticas públicas direcionadas aos interesses das populações locais e na sustentabilidade socioambiental.

Muitas das estratégias para progresso e desenvolvimento da região caracterizaram um período de profundas transformações na Amazônia brasileira em diferentes escalas. Nesse contexto, a conservação do ambiente natural e o seu desenvolvimento não podem ser dissociados (Prates e Bacha 2011). No que concerne a ocupação ou expansão populacional na região, devido à intensificação do desmatamento decorrente desses processos e às questões ambientais de modo geral, os ecossistemas naturais foram significativamente modificados (Lui e Molina 2009; Soares Filho et al. 2008; Fearnside 2005).

Nesse contexto, verifica-se a importância de estudos relacionados à temática socioambiental, que incide na realidade de comunidades locais. A exemplo, os moradores e pescadores artesanais do Lago do Juá e da Área de Proteção Ambiental - APA do Juá, localizados em Santarém, Pará. Assim, o presente estudo teve por objetivos realizar uma caracterização socioeconomica e identificar os principais impactos socioambientais a partir da percepção de moradores e pescadores artesanais locais de uma comunidade ribeirinha que vive no entorno do Lago do Juá, localizado em Santarém, Pará, Brasil.

\section{Material e Métodos}

\section{Área de Estudo}

O município de Santarém está localizado na Mesorregião do Baixo amazonas, à margem direita do Rio Tapajós, na região oeste do estado do Pará, Brasil (Figura 1), no qual há a presença de diverso mosaico de cobertura vegetal, Áreas de Proteção Ambiental (APAs), com, rios, lagos e igarapés (Cardoso et al. 2018). Além disso, na região ocorrem influências de oscilações anuais das cheias e vazão das águas claras do Rio Tapajós e águas barrentas do Rio Amazonas. 
Figura 1. Imagem da área em estudo, com identificação das áreas de influência, município de Santarém, Pará, Brasil.
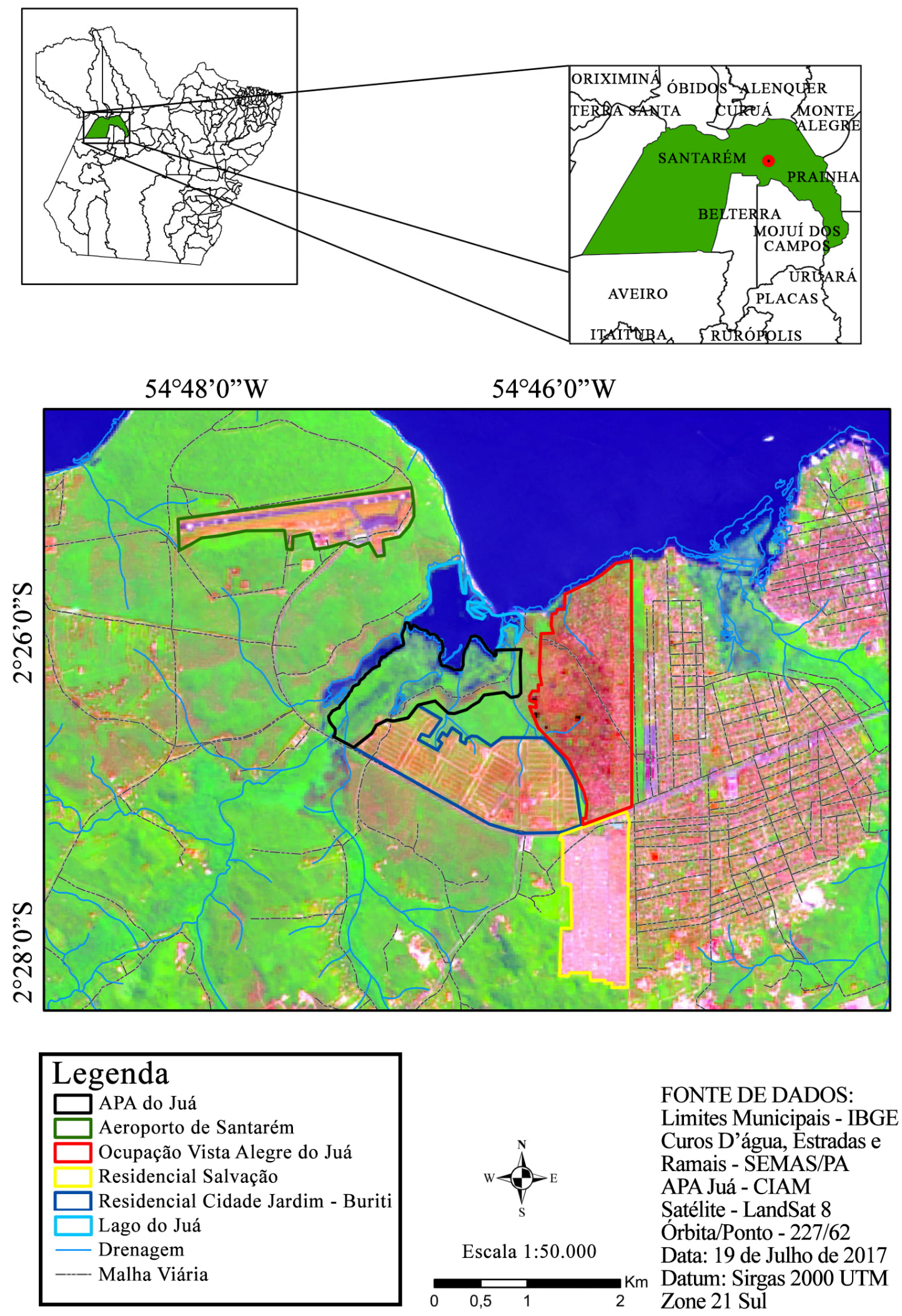

Fonte: Produzido por Rodrigo Martins Rabelo (2018), como serviço prestado aos autores. 
A topografia do município varia com altitudes de $50 \mathrm{~m}$ a $600 \mathrm{~m}$ (Embrapa 2006), a cobertura florestal é abundante, e os recursos hídricos (rios Amazonas, Tapajós e seus afluentes) são responsáveis pelo regime hídrico regional (Sepof 2006). O clima da região é quente e úmido, com temperatura média anual variando entre 25 e $28^{\circ} \mathrm{C}$, a média da umidade relativa do ar é de $86 \%$, além de elevada ocorrência de pluviosidade média $(1920 \mathrm{~mm}$ ) ao longo do ano (Fernandes e Ximenes 2020). A umidade e pluviosidade nessa região são consideradas elevadas, variando de 1.900 a 2.300 mm anuais, com chuvas de 151 a 175 dias por ano, sendo que fevereiro, março e abril são os meses mais chuvosos e agosto, setembro e outubro os meses com menor incidência de chuvas (Rocha et al. 2009).

O lago do Juá (Figura 2A) encontra-se à margem do Rio Tapajós, recebendo efeitos diretos de cheia e vazante do rio (Figura $2 \mathrm{~B}$ ), o que influencia na ocorrência de cenários diferentes (Figura 2C), que variam conforme a época do ano - inverno ou verão em se tratando da região Amazônica. No período de baixa das águas do lago, é possível perceber as faixas de areia nas margens do Rio Tapajós, período em que se forma a praia do Juá, uma das mais atrativas da cidade.

Figura 2. A) Lago do Juá em Santarém, Pará, Brasil. B) Período de cheia. C) Período de vazante: faixa da praia.
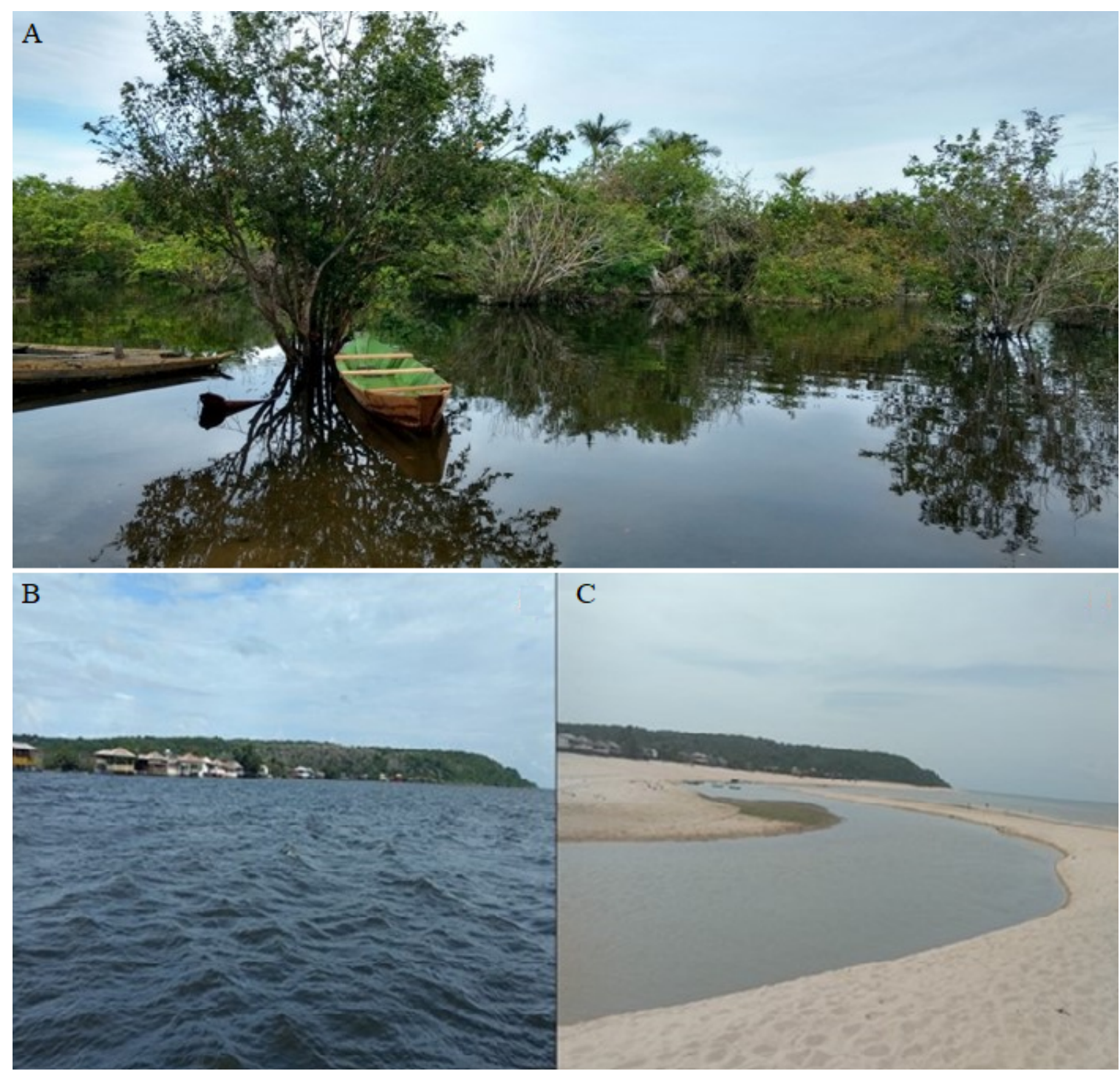


\section{Coleta e Análise dos dados}

A pesquisa foi realizada com moradores e pescadores artesanais que moram na Comunidade do Lago do Juá, em Santarém, Pará e com pescadores artesanais fazem uso do lago para pesca tradicional, porém, residem fora da área do lago, cita-se a presença de moradores e pescadores dos bairros Mapiri e Maracanã, e das comunidades Ramal dos Coelhos e Santa Maria, estas duas localizadas no Projeto de Assentamento Agroextrativista do Eixo Forte (PAE Eixo Forte), em Santarém.

Para realização das entrevistas identificaram-se junto à comunidade "informantes-chaves" que tinham conhecimentos mais detalhados sobre o assunto pesquisado e a amostragem foi determinada pela técnica "Bola de Neve" (Penroid et al. 2003; Baldin e Munhoz 2011). A indicação foi iniciada pela líder da comunidade, e posteriormente cada participante foi indicando outras pessoas que poderiam contribuir, até se fechar a rede de informantes chaves que participaram da pesquisa. Assim, as entrevistas foram realizadas com 25 pessoas, conduzidas com até mais de um morador por domicílio, pois acredita-se que as percepções e relações estabelecidas com o lago são distintas entre os sujeitos.

A etapa de campo foi dividida nas seguintes atividades:

1. Visita inicial para reconhecimento da área a ser pesquisada e identificação dos informanteschave;

2. Roda de conversas para exposição da proposta do trabalho aos moradores, e aquisição de conhecimento geral dos aspectos socioeconômicos e ambientais que envolvem a comunidade. Foi recebida a carta de aceite da comunidade para coleta e uso dos dados;

3. No decorrer da pesquisa socioeconômica, foram realizadas caminhadas, observação e registros fotográficos para reconhecimento da área e identificação de aspectos físicos e socioeconômicos do Lago do Juá;

4. Realização de entrevista estruturada na busca de respostas rápidas, tabuláveis e de fácil contextualização, principalmente dados quantitativos (Gil 2008). Com questões para identificar a idade, gênero, escolaridade, quantidade de pessoas residentes na casa, local de origem da família, motivações para viverem na região do Lago do Juá, atividades econômicas, fonte de renda, organização social existente na comunidade e infraestrutura;

5. Para isso, a pesquisa foi submetida à Plataforma Brasil para Apreciação Ética pelo Comitê de Ética em Pesquisa (CEP), da Universidade do Estado do Pará (UEPA) - Campus XII Tapajós, sendo aprovada pelo parecer no 2.447.030, em 19/12/2017. Durante as entrevistas foram realizados esclarecimentos quanto aos princípios éticos da pesquisa, apresentados com a leitura do Termo de Consentimento Livre e Esclarecido - TCLE;

6. E na última parte da pesquisa de campo, foi utilizado o modelo de entrevista semiestruturada, no qual foi organizado um conjunto de questões sobre a temática estudada (Pádua 2012). Também foi realizada a metodologia da história oral (Alberti 2000), para se conhecer os processos históricos que influenciaram transformação socioambiental na região. Nessa etapa, participaram cinco "informantes-chaves", que residem na comunidade e que foram indicados como detentores de conhecimentos do processo histórico da comunidade do Lago do Juá. O formulário foi divido em questões relacionadas às atividades econômicas, 
problemáticas ambientais, mudanças na região, perspectivas de vida na comunidade, percepção sobre Área de Preservação Ambiental e conflitos.

Os entrevistados foram identificados com a letra J e um número arábico, no sentido de manter o anonimato dos mesmos. Para análise, os dados socioeconômicos foram sistematizados e tabulados em bancos de dados no programa Excel for Windows $2010^{\circ}$.

Foi feita análise textual dos discursos dos entrevistados, e os dados obtidos nas entrevistas permitiram produzir novos conhecimentos, que provêm diretamente de experiências vividas, as quais são sempre expressão concreta e delimitada de uma prática social e histórica mais ampla (Jara 2012). Para isso os dados foram tratados pela Análise Textual Discursiva, conforme Torres et al. (2008) e os dados socioeconômicos pela estatística descritiva.

\section{Resultados e Discussão}

\section{Aspectos históricos da ocupação da região do Lago do Juá}

Nas margens do Lago do Juá existem cerca de 15 casas, parte delas habitadas por pescadores artesanais que nasceram e cresceram na comunidade e que utilizam o lago para o desenvolvimento da atividade pesqueira; as demais casas são utilizadas para visitações nos finais de semana e período de férias escolares (janeiro e julho) - são as chamadas casas de veraneio. Seis famílias residem efetivamente na Comunidade do Juá, todas com algum grau de parentesco. A moradora mais antiga da comunidade tem 65 anos e reside há mais de sessenta anos.

Os lagos têm conexões com os rios, ou seja, são formas de ligação com estes, assim, têm dinâmicas de subida e baixas de água influenciadas pela dinâmica dos rios, sendo que alguns lagos secam parcialmente, enquanto outros ficam completamente secos, podendo chegar ao nível mais baixo das águas dos rios que os abastecem (Darwich et al. 2005).

No período de baixa das águas do lago, as praias Maracanã, Salvação e Juá acabam por constituir uniformidade na paisagem e tornam-se pontos turísticos e de lazer pelas facilidades de acesso e proximidade do núcleo urbano da cidade. Nos lagos da região do Baixo Amazonas, ocorrem pescarias durante todo o ano, porém, de forma mais intensificada no período que as águas começam baixar e os peixes começam a migrar dos lagos para o canal do rio (Corrêa et al. 2018).

Segundo os pescadores entrevistados, é no período de vazante que eles passam a intensificar a frequência ao Lago do Juá. Isso ocorre pela oferta de peixe ser maior no período da baixa das águas. Essa frequência ocorre para a pesca de subsistência e, para comercialização do pescado (Figura 3). Nesse período, os pescadores artesanais ficam horas no lago a procura principalmente de uma espécie de pescado, que chamam vulgarmente de jaraqui, comercializado inclusive nas margens da Rodovia Engenheiro Fernando Guilhon, principal via de acesso ao lago.

Segundo os moradores, durante muito tempo o lago foi restrito ao turismo, ao lazer e a pesca de subsistência. Mas, o processo de expansão urbana entorno do lago tem ocasionado impactos negativos (assoreamento, retirada da vegetação, alteração da água do lago, entre outros impactos), oriundos das ações antropogênicas que direta e indiretamente comprometem as características naturais do lago. 
Figura 3. Pesca de subsistência no Lago do Juá, Santarém, Pará, Brasil.

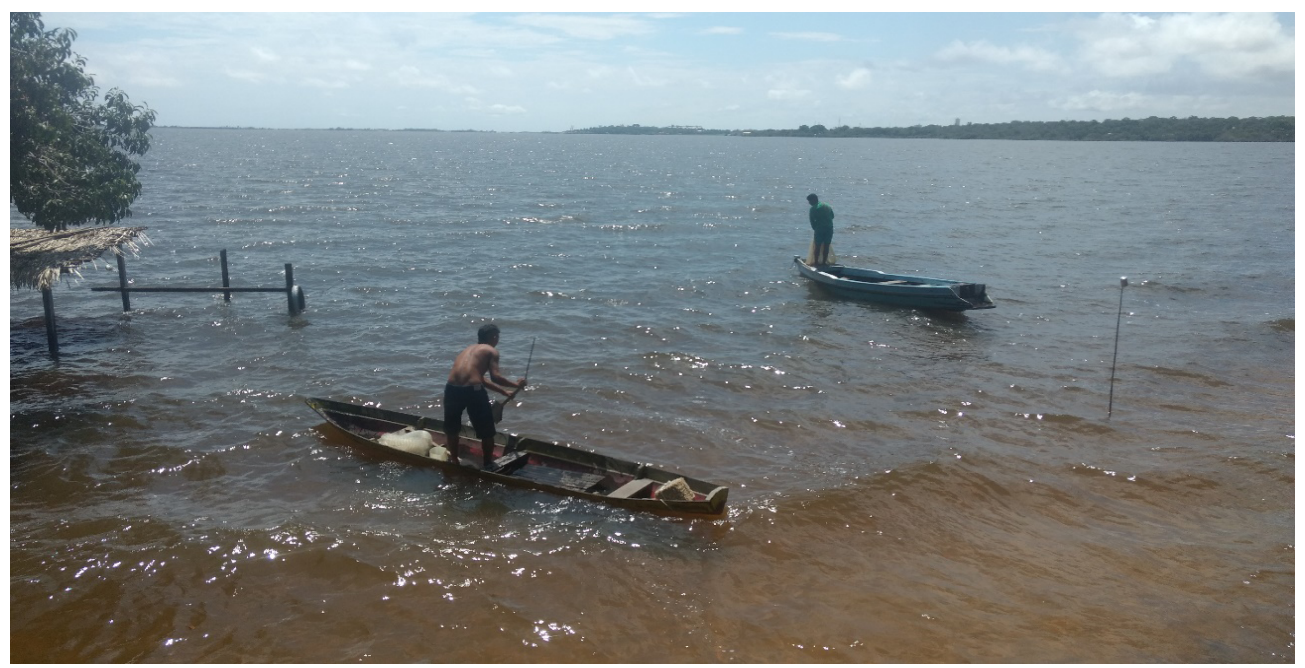

A fim de compreender as transformações que ocorreram no lago e seu entorno, assim como, no modo de vida dos moradores da Comunidade do Juá, foi proposto as pessoas que participaram da pesquisa que relatassem suas percepções indicando o ano dos acontecimentos que influenciaram nas mudanças. As datas informadas por eles podem não ser tão fiéis o ano em que o evento ocorreu, porém, atendem as expectativas deste estudo que é conhecer a região e os impactos ocorridos a partir dos relatos das pessoas que vivenciaram essas transformações.

Segundo relatos dos entrevistados, foi no ano de 1953, que chegou a Primeira Família para ocupar os espaços na região de entorno do Lago do Juá e assim foi instituída a Comunidade do Lago do Juá. Inicialmente a família era constituída por um casal e mais seis filhos (quatro homens e duas mulheres). A abertura da estrada principal que dá acesso à Rodovia Engenheiro Fernando Guilhon ocorreu há mais de 65 anos, ou seja, antes da ocupação do espaço.

Os primeiros moradores vieram da Comunidade de Urucurituba (Região de Várzea em Santarém) devido ao fenômeno de terras caídas. Tal fenômeno caracteriza-se como resultado da erosão fluvial, que é comum ocorrer às margens de rios de águas claras e com fluxo de água mais acelerado (Ribeiro Filho 2012).

De acordo com Fraxe (2004), o modo de vida de populações ribeirinhas tradicionais, é fundamentado pela integração de atividades agrícolas e extrativismo vegetal e/ou animal, dependendo assim, da coleta de produtos da floresta, dos rios e das terras da várzea amazônica.

Pescam durante o verão e inverno amazônico. No período de vazante, além da pesca de subsistência e artesanal, fazem o cultivo de árvores frutíferas, hortas e plantas medicinais, e criam pequenos animais, como galinhas.

Em 1979, foi construído a primeiro prédio da Igreja Católica, Nossa Senhora de Fátima, segundo os entrevistados a religiosidade sempre esteve presente. O prédio da igreja era de madeira e foi construído pelos próprios moradores da comunidade. Com as enchentes, e o número de moradores reduzindo, atualmente se deslocam para os templos da cidade ou das comunidades do Eixo Forte.

Em 1985, por iniciativa dos moradores e recursos do poder público municipal, o prédio da primeira escola foi construído. A estrutura era de madeira e coberta de palha. Antes disso, os membros da família ficavam sem estudar. Anos depois, essa construção foi destruída pelas enchentes, e na década de 1990 foi construída novamente em madeira, no entanto, coberta de telhas 
fibrocimento. O ensino fundamental era ofertado às crianças por meio de turmas multisseriadas, nessa modalidade de ensino, em uma mesma sala de aula, a professora atuava simultaneamente, ensinando os conteúdos para alunos com idades e níveis de conhecimento distintos, inseridos em diferentes anos do ensino fundamental. A construção da escola permaneceu até meados dos anos 2000. Sem prédio escolar, alguns não deram continuidade nos estudos. Outros fizeram e fazem o deslocamento para outras áreas da cidade para estudar, como ocorre até hoje em maioria, ou ainda saem definitivamente da comunidade.

No ano de 2009, durante o período de cheia do rio, o prédio da igreja foi destruído, assim como outras construções locais, como residências. Segundo os moradores, atualmente, a Igreja, a escola e o posto de saúde não são construídos na Comunidade do Juá, por conta das enchentes e pelo número limitado de moradores locais que vivem na comunidade em tempo integral. Isso mostra que além de fatores antrópicos, fatores ecológicos também exercem influência nos processos de uso e ocupação do espaço.

Do total de entrevistados que residem na comunidade, $72 \%$ informaram que utilizam a água do lago para realizar seus afazeres domésticos, como exemplo: banho, lazer, pesca, e alguns relataram que também utilizam para beber (44\%), o que demonstra a importância desse ecossistema no cotidiano dessas famílias. Não houve relatos de tratamento dessa água. As habitações são quase que exclusivamente de madeira e suspensas devido à cheia e vazante das águas (Figura 4). Das 15 casas que estão nas margens do lago, apenas uma é de alvenaria.

Conforme os entrevistados, a atividade pesqueira configura-se como uma das mais importantes atividades econômicas na comunidade, sendo importante fonte de alimento, renda e também de lazer. Isto corrobora com Vaz et al. (2017), que em estudo realizado sobre a pesca artesanal no lago do Maicá, também localizado em Santarém, relataram que a pesca artesanal tem importante finalidade na geração de renda, pois, é uma atividade que garante alimento para as populações locais, sendo fonte de subsistência para os moradores da comunidade.

Figura 4. Construções características na comunidade do Lago do Juá, Santarém, Pará, Brasil.

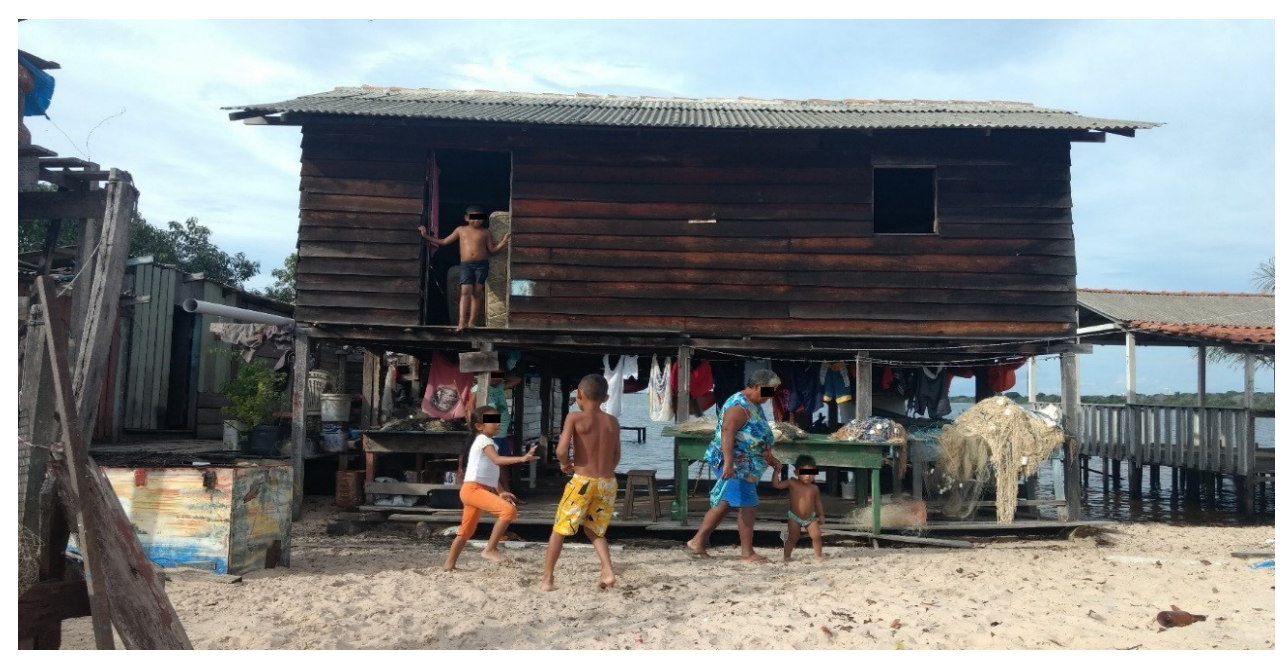

No entanto, as diversas formas de usos em ambientes aquáticos, associadas à especulação imobiliária em espaços próximos a lagos e rios, acarretam em transformações e impactos nesses ecossistemas naturais, como por exemplo, diminuição da produtividade de espécies de peixes, 
ameaças de extinção, além do aumento de problemas socioambientais e erosão cultural, afetando assim, funções ecológicas (Corrêa et al. 2018) e sociais, essenciais desses espaços.

As mulheres geralmente trabalham com serviços domésticos; com pesca de subsistência, incluindo a confecção dos materiais usados nesta atividade e limpeza do peixe. Coelho et al. (2020), em estudo realizado sobre a pesca de camarão em Santarém, também relataram que apesar das mulheres não serem citadas como responsáveis pela confecção do apetrecho e nem pela pesca efetiva, elas participam e auxiliam em outras funções ao longo da cadeia produtiva, como o beneficiamento, a embalagem e a comercialização do pescado em feiras livres e mercados da cidade, somado as diversas outras tarefas domésticas que realizam.

De acordo com Valencio e Venturato (2009), as mulheres passam a ocupar o papel de parceiras dos próprios maridos e, através do trabalho, contribuem com a renda familiar. Segundo os autores, enquanto os homens colocam a rede no barco, a elas cabe a função de retirar os peixes da rede e armazená-los em espaço refrigerado. As mulheres também cuidam da alimentação do esposo, organizando, por exemplo lanche, agasalho, entre outros, que garantam o mínimo de conforto no trabalho da pesca.

Acypreste (2015) destaca que a pesca artesanal para os ribeirinhos, além de ser uma atividade laboral, uma estratégia de obtenção de alimentos, tem também função de lazer e descanso, e segundo a autora, o que acentua a diferença entre homens e mulheres quanto à atividade de pesca, pois, enquanto os homens dedicam-se exclusivamente à pesca, com horários estipulados para realização da atividade, as mulheres têm como atribuições além de contribuir na pesca, a realização também dos afazeres domésticos.

Pescadoras artesanais conseguiram alguns avanços dentro da atividade pesqueira, mas a invisibilidade de sua produção ainda é um entrave que não foi vencido, principalmente dentro de suas entidades representativas da classe, que, em sua maioria, são ocupadas por homens (Sousa et al. 2018).

Além das atividades com a pesca, os moradores da comunidade do Juá cultivam hortaliças em hortas domésticas em seus quintais (Figura 5). A nomenclatura foi estabelecida pelos próprios entrevistados. As plantas são cultivadas em recipientes colocados de forma suspensa ao chão, pois no período das chuvas, o Rio Tapajós enche cobrindo toda extensão de terra ao redor das casas.

Figura 5. Horta doméstica no Lago do Juá, Santarém, Pará, Brasil.

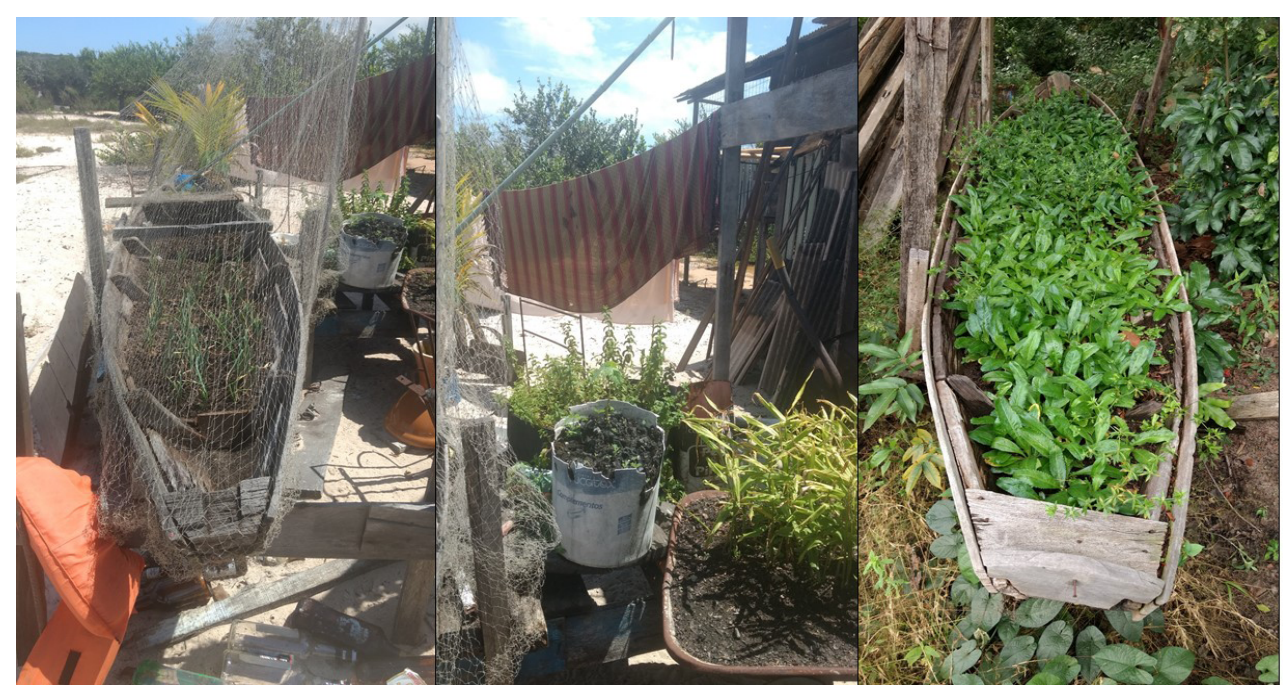


Os moradores da comunidade cultivam cebolinha, chicória e coentro que são utilizados na alimentação familiar e também plantas medicinais como mangarataia, boldo, coramina, hortelãzinho, erva cidreira que auxiliam no tratamento de algumas doenças. Além das plantas, os moradores criam pequenos animais, como galinhas, como forma de contribuir na alimentação da família. Existe pouca diversidade de espécies frutíferas tais como o murici, tucumã, coco e juru. Muitos indivíduos de várias espécies vegetais, segundo 56\% dos entrevistados, foram levados pelas enchentes ou suprimidos pela ocupação do entorno. Pode ser também que algumas dessas espécies não tenham se adaptado ao regime de cheia e vazante da região. Os entrevistados ainda informaram que o volume e a variedade das espécies de peixes, das espécies cultivadas reduziu muito, quando comparado ao que se tinha há seis anos, por exemplo.

Embora todos os entrevistados afirmassem ter conhecimento que o Lago do Juá está situado no limite com a Área de Proteção Ambiental do Juá, 68\% afirmaram que não sabem tecnicamente o quem vem ser uma APA. A representante da comunidade afirma ter participado da reunião para a criação do Conselho Gestor da APA por julgar importante a criação da Área de Proteção Ambiental.

A Associação de Moradores e Amigos do Juá - AMAJUA, é responsável por cuidar dos assuntos da comunidade, a representante dessa associação é uma mulher, que foi nomeada também como membro suplente do Conselho Gestor da Área de Proteção Ambiental - APA do Juá, trata-se da moradora mais antiga da comunidade. Nota-se aqui, que o papel da mulher vai além dos afazeres domésticos e do auxílio aos maridos nas atividades relacionadas à pesca. Também participam de forma ativa nas decisões da comunidade, o que demonstra que o protagonismo feminino vem crescendo em diversos setores da sociedade. Portanto, mesmo com a grande participação dos homens, o envolvimento das mulheres vem crescendo na pesca na região do Lago do Juá, visto que sua participação vai além das atividades domésticas, com destaque para o envolvimento em instâncias colegiadas e políticas.

Sousa et al. (2018, p. 157), ao pesquisarem sobre o protagonismo socioeconômico de pescadoras artesanais em uma região de várzea em Santarém, destacam que as pescadoras artesanais conseguiram alguns avanços dentro da atividade pesqueira, porém, "a invisibilidade de sua produção ainda é um entrave que não foi vencido, principalmente dentro de suas entidades representativas da classe, a exemplo das diretorias das Colônias de Pescadores que, em sua maioria, são ocupadas por homens".

Maneschy et al. (1995) destacam que existe invisibilidade da participação das mulheres na produção pesqueira, o que provoca entraves também nas articulações políticas dos movimentos sociais desse setor.

Em estudo realizado por Di Ciommo (2007) com pescadores em uma Reserva Extrativista Marinha (BA), foi apresentado que as mulheres estão vinculadas a atividades relacionadas ao bemestar e sobrevivência da família, essas mulheres segundo o estudo, manifestaram interesse em obter independência financeira e participar de forma mais ativa das associações comunitárias, portanto, o autor concluiu que essas demandas podem ser consideradas ações transformadoras na relação de gênero, o que contribui para o empoderamento das mulheres.

Sendo assim, a participação feminina das mulheres na Comunidade do Lago Juá, é fundamental na valorização e reconhecimento de seu papel na atividade pesqueira, na organização familiar e participação política. 


\section{Aspectos socioeconômicos}

Foram entrevistados dezoito homens (72\%) e entrevistadas sete mulheres (28\%), denotando uma relevante participação dos homens que pode ser atribuída ao fato que a atividade de pesca muitas vezes é vista como uma atividade masculina, porém, como abordado no tópico anterior, vem ocorrendo mudanças quanto a participação feminina. Esses dados corroboram com Corrêa et al. (2018), que identificaram apenas $27 \%$ de mulheres exercendo a atividade de pesca no Lago Juá, Santarém (PA), assim como Silva e Braga (2016) que observaram o percentual de aproximadamente 24\% de mulheres atuando na pesca, na comunidade de Surucuá, na Reserva Extrativista Tapajós Arapiuns (Santarém).

Segundo Sousa et al. (2018, p. 148), a atividade da pesca artesanal na região amazônica é organizada com divisão de trabalho e participação de todos os integrantes da família, e as mulheres ao assumirem mais responsabilidades no desenvolvimento da atividade da pesca, "começaram a se mobilizar em busca de garantir equidade no acesso às políticas públicas, na seguridade social e previdenciária direcionadas ao setor pesqueiro". Assim, os autores destacam que esse contexto contribuiu para redução de desigualdades históricas existentes, o que vem contribuindo para se dar maior visibilidade da participação da mulher no setor da pesca artesanal e seu empoderamento social, político e econômico.

Dos participantes da pesquisa, $72 \%$ residem na comunidade. Vale ressaltar que uma residência em específico chega a abrigar mais de 20 pessoas. Os outros $28 \%$ dos participantes foram entrevistados de áreas e residências distintas do município, a citar: um residente do bairro Mapiri, um do bairro Maracanã, um do bairro Salvação, dois da comunidade Ramal dos Coelhos e dois da comunidade Santa Maria.

Atribui-se a presença de pescadores de diferentes áreas do município à oferta de recursos pesqueiros no ecossistema estudado, pois na concepção dos pescadores é mais acentuada (em volume e riqueza de espécies). Além disso, de acordo com eles, outros ecossistemas aquáticos das proximidades, como o Lago do Mapiri e os igarapés das comunidades do assentamento PAE Eixo Forte apresentam sinais de degradação, reduzindo a oferta de peixes nestes outros ecossistemas.

A faixa etária dos entrevistados variou de 18 a 35 anos (44\%), seguido de $40 \%$ com idade de 49 a 63 anos, 12\% com idade de 35 a 49 anos e a minoria com idade variando entre 63 e 77 anos (4\%). Este último dado pode estar relacionado ao fato de os pescadores não serem aposentados ou ainda utilizarem a pesca artesanal como complementação de sua renda familiar.

Quanto à escolaridade, a maioria (52\%) informou ter nível fundamental completo, seguido de nível médio incompleto (28\%), e por último ensino médio completo (20\%). Essa realidade está associada inicialmente ao difícil acesso ao ensino básico, ocasionado pela ausência de escola na comunidade. Alia-se a isto, a falta de incentivo por parte dos familiares dos pescadores que tinham a pesca como atividade mais importante do que os estudos.

Isto corrobora com trabalhos de Santos et al. (2005) e Borcem et al. (2011), que afirmam que, em geral, o acesso à escola formal pelos pescadores por eles estudados não era de fácil acesso durante o período de infância e adolescência dos mesmos. Os autores destacam ainda, que por os pescadores já ajudarem trabalhando na pesca, nessa faixa etária, ocorria a incompatibilidade de horários das aulas e do trabalho, além disso a atividade laboral na pesca causava cansaço físico, que afetavam no estímulo para estudar, assim, ocorreu alta taxa de evasão escolar. 
Os serviços de posto de saúde, água encanada e energia elétrica nunca existiram na Comunidade do Lago do Juá. O atendimento à saúde sempre ocorreu no centro da cidade ou em comunidades vizinhas, a citar a Comunidade Cucurunã (PAE Eixo Forte), onde os moradores fazem o deslocamento de ônibus até a comunidade.

A maioria dos entrevistados alegou trabalhar desde muito cedo para contribuir com o sustento da família, o que caracteriza a participação de um público com baixo nível de escolaridade, contudo não foram identificados analfabetos na amostra estudada. A realidade socioeconômica dos moradores e pescadores artesanais que atuam no Lago do Juá é semelhante a de outras comunidades ribeirinhas estudadas na Amazônia, sobretudo quanto ao tipo e tempo de moradia e ao saneamento básico.

De acordo Franco et al. (2015) e Sousa et al. (2018), em comunidades ribeirinhas as casas são construídas de madeira ou mistas com outros tipos de materiais, sendo poucas as feitas totalmente de alvenaria; normalmente ocorre captação de água dos rios, mas há alguns casos de existência de poços artesianos, porém, em geral, usualmente não há tratamento da água para o consumo; o lançamento do esgoto é realizado por meio de fossas sépticas ou a céu aberto.

Com a expansão urbana do município, o uso e ocupação do lago ficaram a cada ano mais acentuados, promovendo impactos sociais e ambientais significativos que vêm afetando na qualidade de vida e do ambiente. Os relatos a seguir expressam alguns desses impactos socioambientais e seus efeitos no Lago do Juá:

\footnotetext{
“Tinha riqueza de peixes, a água era limpinha, dava pra beber. Hoje eu preciso atravessar para buscar água para beber e cozinhar. Pego água na casa da minha filha, que mora na Salvação. Lá tem poço" (relato entrevistado J1).
}

\begin{abstract}
"Antes mesmo na seca não se andava no lago, hoje já anda no meio do lago. As fontes que se tinha não tem mais" (relato entrevistado J2). "Em 2004 teve tentativa de ocupação, mas a comunidade interviu. Mas, em 2006 começou as atividades de mergulho e arrastão, algumas espécies não existem mais" (relato entrevistado J3).

"Desde 2008 reduziu a quantidade do pescado. Com as ocupações os peixes tornaram-se mais escassos. A água tá mais escura. Muito desmatamento tem tido por aqui. A vegetação não se recuperou" (relato entrevistado J3).

"Sobre as perspectivas de vida no lago... não sei responder. Tem tanta coisa acontecendo que a gente só pensa o pior, mas a gente tem ainda esperança que as coisas melhorem por aqui" (relato entrevistado J10).
\end{abstract}

Os relatos dos entrevistados apontam que ações antropogênicas distintas e complementares têm levado a transformações socioambientais significativas e até mesmo irreversíveis no lago. Entres as principais alterações estão o assoreamento atribuído ao Aeroporto de Santarém, o que pode ser percebido na seguinte fala de um dos entrevistados:

"Quando chove a galeria do aeroporto arrasta tudo. A água desce muito forte. Só não escorre mais porque tem caixa que amortizam a força da água" (relato pescador J2). 
De acordo com os “informantes-chaves", a desembocadura da galeria de escoamento das águas pluviais da pista do Aeroporto (Figura 6) tem contribuído de forma significativa para o assoreamento do lago desde a sua implantação, em 1974, e se intensifica a cada período de chuva.

Figura 6. Galeria do aeroporto, no município de Santarém, Pará, Brasil.

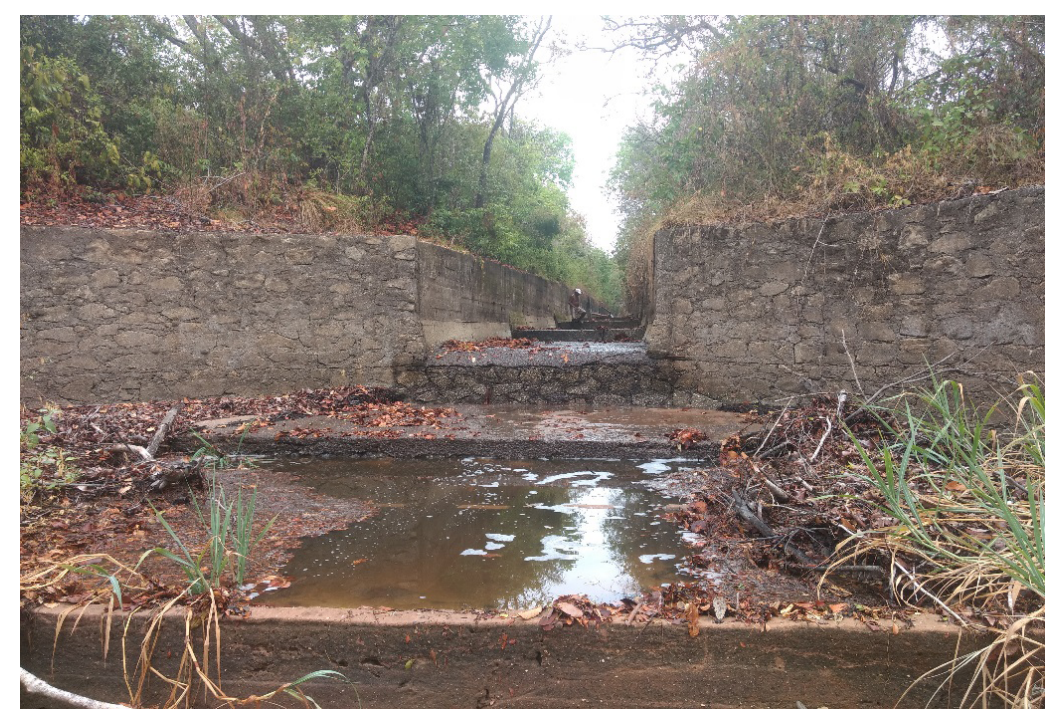

Os materiais depositados na galeria são arrastados com a força da chuva diretamente para o lago, sendo, segundo os entrevistados, o principal agente causador do assoreamento no lago. Ainda segundo eles, além do assoreamento, o desmatamento para instalação dos empreendimentos imobiliários também tem alterado o lago. Ao Residencial Cidade Jardim - Buriti, de responsabilidade da Salvação Empreendimentos Imobiliários LTDA. (SISA), cujo nome fantasia é Buriti Imóveis, os entrevistados remetem a supressão da cobertura vegetal de área próxima ao lago, o que facilitou o escoamento pluvial e o carregamento de sedimentos desde 2012.

A maioria dos entrevistados (67\%) informou que a retirada da cobertura vegetal impactou diretamente o lago, pois facilitou o escoamento de efluentes, que além de alterarem os aspectos estéticos da água, interferiram na ocorrência de peixes no lago.

Dos entrevistados, $48 \%$ afirmaram que os peixes estão morrendo com os impactos causados no lago, reduzindo principalmente a ocorrência de peixes ornamentais. Um pescador afirmou ter exercido simultaneamente no lago a pesca artesanal e a pesca ornamental, que se diferenciam, segundo ele, de acordo com a espécie de peixe capturada. Mas, deixou de exercer a pesca ornamental desde 2016.

Em pesquisa conduzida por Coêlho et al. (2020) em Santarém, foi relatada que a situação da pesca de camarão vem piorando com o passar dos anos, principalmente devido ao aumento da concorrência, o que gera perdas de espaços de trabalho e sinais de diminuição dos estoques naturais ocasionados pelo crescente esforço de pesca, além disso, mencionaram a escassez do recurso e a queda na quantidade de camarão pescado, mas ao mesmo tempo, os pescadores demostraram pouca preocupação com as práticas de manejo que garantam a sustentabilidade da atividade.

Segundo os entrevistados, muitas espécies endêmicas também foram perdidas, sobretudo orquídeas características do Lago do Juá, a seguir relatos de dois dos entrevistados que participaram desta pesquisa: 


\begin{abstract}
"As empresas que desmataram ao redor do lago. Desmataram muito. O lago era fundo. Tinha muitas árvores. Agora morreram tudo" (relato entrevistado J18).

"A quantidade de peixes diminuiu, o sabor do pescado já não é o mesmo. O rio secou muito e o lago é só lama" (relato entrevistado J24).
\end{abstract}

Conforme os entrevistados, a quantidade de espécies animais e vegetais é muito inferior a de algumas décadas atrás. De acordo com Suemitsu et al. (2013), devido intenso processo ocupação e de desmatamento na região do Lago do Juá, está ocorrendo a extinção de diversas espécies endêmicas e raras no local. Cardoso et al. (2017) destacam ainda que a alteração no ecossistema, afeta a conservação de muitas espécies de vegetais e animais, além de comprometer a qualidade dos recursos naturais e a saúde e o bem-estar das pessoas que vivem no local. Portanto, a vegetação e a ictiofauna da área foram e continuam sendo afetadas pela ação humana.

Os entrevistados atribuem, ainda, ao Residencial Salvação, que faz parte do Programa "Minha casa, Minha vida" do Governo Federal, o lançamento de efluentes urbanos oriundos do esgoto doméstico das casas do Residencial, conforme relato a seguir:

"Há 20 anos trabalhava com pesca ornamental e artesanal. Nos últimos três anos só trabalho com pesca artesanal. Os peixes ornamentais sumiram. Perderam a qualidade. Muitos chegavam mortos. Quando trabalhava com pesca ornamental, prestava serviço para três empresas. Uma não lembro o nome. As outras são: Tapajós Aquarius e Amazon Fish" (relato entrevistado J3).

Os moradores enfatizaram ainda o episódio ocorrido em 2014, quando as águas pluviais escoaram com sedimentos desagregados pela enxurrada diretamente no leito do lago. A água que antes era utilizada em todos os afazeres domésticos, inclusive para consumo humano, beber e cozer os alimentos, passou a ser consumida com menos intensidade.

Conforme Leopoldo et al. (2020), a exploração desenfreada dos recursos naturais, ocupação e uso descontrolado dos solos, acarretam nos avanços da degradação ambiental, impactando assim, os ecossistemas naturais, tais aspectos são reflexos de uma concepção avessa da visão ecológica que por vezes vão também em desacordo com a papel e dimensão cultural e social que possuem.

Todos os entrevistados declararam que em 2014, após chuvas intensas, foram perceptíveis mudanças no lago, devido os sedimentos provenientes das obras do Residencial Salvação. Segundo eles naquele período foi possível perceber a ocorrência com maior frequência de algumas doenças, como infecções intestinais, coceira e/ou irritações na pele. Segundo Silva et al. (2020), a falta de estações de tratamento de esgoto nos municípios pode resultar no aumento da toxidade pelo potencial acúmulo de poluentes e na contaminação dos recursos hídricos, que geram impactos na saúde humana e ambiental. A comunidade não dispõe de sistema de abastecimento de água e 44\% dos entrevistados informaram que precisam atravessar para a outra margem do lago - Área da Praia Salvação - para buscar água com moradores do outro "lado" que possuem poço. Essa água, eles utilizam para beber e cozinhar os alimentos.

Para os entrevistados pela pesquisa, assim como os empreendimentos imobiliários, as ocupações desordenadas nas adjacências também degradam o lago. Com o aparecimento da Ocupação Vista Alegre do Juá, além da perda da tranquilidade e do sossego (intensificadas por 
questões de insegurança), os moradores do Juá relatam que o cotidiano e as relações sociais locais foram severamente alterados, sobretudo em função da contínua e extensiva ocupação no entorno do lago com desmatamento extensivo e intensivo. Isto mencionado nos seguintes relatos de dois entrevistados desta pesquisa:

\footnotetext{
"Por conta das invasões aumentou os furtos, perdemos a tranquilidade, aumentou e muito a violência. Muitos nem querem pescar, vem fazer outras coisas como usar drogas" (relato entrevistado J11).

"Essa ocupação Vista Alegre do Juá não tem sido nada boa. Não demora muito estarão aqui no lago" (relato entrevistado J1).
}

Os entrevistados ainda relatam que a noite, muitos dos pescadores "de fora" fazem pesca de mergulho, além de praticarem pequenos furtos, principalmente de materiais úteis à pesca, como: basqueta, malhadeira e o próprio pescado. Aumentando o nível de insegurança na comunidade. Como resultado surge o conflito de interesses entre pescadores locais e os "de fora" pelo uso e usufruto do lago e, consequentemente, dos recursos pesqueiros nele presente, conforme relatos a seguir:

\footnotetext{
"Outra coisa é o número de pescadores de fora que tem vindo pra cá. Querem limitar o nosso acesso como se tivessem mais direito que nós. Que moramos aqui” (relato entrevistado J2).

"O principal problema é a disputa pelos peixes. O lago tem se tornado pequeno pra tanta gente que tem vindo pra cá" (relato entrevistado J12).
}

Esse conflito de interesses relacionados à pesca no Lago do Juá promove disputas pelos recursos pesqueiros e a exploração desenfreada destes, devido à sobreposição e modos diferenciados de apropriação e uso de áreas de pesca, sendo então essencial que a comunidade tome medidas formais ou informais de uso/ou apropriação do Lago que possibilitem uma conciliação entres os atores envolvidos, que se configurem num Acordo de Pesca no Lago do Juá, para o estabelecimento de regras e/ou acordos de caráter coletivo de forma que seja realizado o uso racional e ecologicamente viável dos recursos pesqueiros desse espaço (Cardoso et al. 2018). Esses autores inclusive apresentam exemplos de experiências exitosas como: projetos Mamirauá (Museu Goeldi e governo do Amazonas), na região de Tefé; Iara (IBAMA - GTZ), na região de Santarém e Pyrá (UFAM), em alguns lagos próximos a Manaus.

Segundo os relatos, pode-se afirmar ainda, que o pescado se tornou um recurso valioso, objeto de disputa entre diferentes atores em contextos de conflito: os pescadores locais do Juá sentemse ameaçados com a entrada de embarcações no lago, porque temem a redução dos estoques pesqueiros. Assim, de acordo com Cardoso et al. (2018), restrições ao acesso e uso de determinadas áreas de pesca no lago foram uma das medidas tomadas pelos pescadores, de modo que estas são regidas por regras informais estabelecidas pelos próprios moradores do Juá, mas que nem sempre são respeitadas.

Para as pessoas supracitadas, na ausência de acordo de pesca, acordos informais entre os pescadores e os comunitários, que considerem o uso comum ou gestão compartilhada do Lago poderá ser solução para a problemática, havendo necessidade de serem estabelecidos regras e/ou 
acordos de caráter coletivo, de forma que seja realizado o uso racional e ecologicamente viável dos recursos pesqueiros lacustres do Juá, além da aplicabilidade de políticas públicas e sociais que sejam efetivas em ações para fiscalizar, monitorar sujeitos, empresas e/ou instituições que desenvolvam processos e/ou atividades que comprometam a qualidade ecológica do lago e consequentemente da qualidade de vida das pessoas que vivem na comunidade.

Nessa perspectiva, os conflitos socioambientais existentes, envolvem grupos sociais que se apropriam, usam e fazem significações diferenciadas do espaço, e se originam quando as formas sociais de pelo menos um dos grupos é ameaçada, resultando em disputa por apropriação de uma mesma base de recursos ou de bases distintas, mas interligadas por interações ecossistêmicas (Acselrad 2004).

A partir desse contexto, Little (2002) elucida que a definição de territorialidade, perpassa por ações desenvolvidas pelo empenho coletivo de um grupo social ao ocupar, utilizar e controlar determinado ambiente com qual se identifica.

Assim, os conflitos socioambientais estão interligados à consolidação de territorialidades específicas, no qual, mobilizações de grupos sociais para conservação ambiental, sobretudo na região amazônica, estão relacionadas com uma "politização do saber sobre a natureza" (Almeida 2008, p. 14) e, que é ampliada também para uma politização da própria natureza (Almeida 1996; 2004; 2009). Essa politização também é constatada por Zacardi, Ponte e Silva (2014) ao caracterizarem a pesca e o perfil dos pescadores artesanais em uma comunidade às margens do rio Tapajós, Estado do Pará. Assim como em um relato de um uns entrevistados que participaram desta pesquisa, a seguir:

\footnotetext{
"Hoje tem uma luta no Juá, pela conservação do lago. Tem luta para conservar o que resta. Existe o conflito contra a Buriti, contra a ocupação. Há conflito entre os pescadores. Um quer mais que outro. Seria mais fácil se as leis fossem respeitadas, que funcionassem. SEMA e IBAMA não atuam como deveriam" (relato entrevistado J24).
}

Conforme Chaves et al. (2008), é essencial ressaltar que a mobilização e a organização do movimento de pescadores ribeirinhos são importantes para sustentação da representatividade social desses grupos, para que possam lutar e conquistar seus direitos à cidadania, à partir de uma gestão democrática e participativa para as tomadas de decisão quanto ao uso sustentável dos recursos naturais, sendo que este último, vem sofrendo transformações conforme as novas realidades estabelecidas na Amazônia, de âmbito político, social e ambiental.

Como mencionado anteriormente, em se tratando do Lago do Juá, os conflitos socioambientais são quanto ao uso e ocupação do lago e seu entorno; ou seja, o uso e o usufruto dos recursos naturais nele presentes, principalmente os pesqueiros, configurando-se o grande desafio de estabelecer um equilíbrio das relações entre os diferentes atores envolvidos, tanto no ambiente interno, quanto no externo ao lago.

Assim, nesse contexto local, os "Acordos de Pesca" podem ser considerados como estratégias de grande importância como um processo de gestão pesqueira, regulando assim a atividade conforme os interesses da população do lago, oportunizando a sustentabilidade em nível local e promovendo a qualidade de vida (Cardoso et al. 2018).

Portanto, estudar e analisar sobre conflitos socioambientais, é uma estratégia metodológica muito importante para se compreender a realidade da ecologia política, cuja essência está pautada 
na justiça social do uso de recursos naturais, ou seja, pesquisar conflitos entre grupos sociais relacionados ao acesso e uso de um determinado recurso, como água, terra, flora, fauna, entre outros (Cunha 2004; Turner 2004).

O complexo do Lago do Juá, assim como outros ecossistemas amazônicos, é constituído por diversas e complexas variáveis que envolvem tanto fatores biológicos e físicos, como também aspectos sociais, culturais, econômicos e políticos. Logo, pensar sobre o processo de construção das relações sociais dos povos amazônicos é tratar de compreender o complexo sistema de organização política, econômica e territorial das comunidades, que refletem as condições de apropriação do espaço, de adaptabilidade, e, sobretudo, de subsunção da natureza (Rapozo 2015).

Entende-se que além da identificação e avalição dos impactos socioambientais gerados, é importante uma análise profunda do seu reflexo na sociedade/comunidade, com ênfase na interligação existente entre os atores sociais envolvidos e o ambiente natural impactado.

\section{Considerações Finais}

O Lago do Juá é reconhecidamente um espaço de reprodução ecológica e social, com importância econômica e política para a região, principalmente para moradores e pescadores que fazem parte da Comunidade do Lago do Juá. As relações entre atores sociais distintos e espaço natural geram complexos conflitos de interesses que culminam geralmente na disputa pela apropriação do espaço e acesso e uso de recursos naturais nele existente.

A análise da interação entre os atores sociais e o lago, ressalta a complexidade socioambiental existente e a ineficácia das políticas públicas que têm contribuído para processos contínuos de ocupação e uso, modificando espaços naturais como o Lago do Juá, alterando a qualidade da água e dos recursos pesqueiros, assim como perda da biodiversidade, com ênfase à ictiofauna e à flora.

Os dados só reforçam a problemática socioambiental existente na Área de Proteção Ambiental do Juá, no lago e seu entorno, fragilizada pela própria legislação vigente em que a lei de criação da APA não assegura a proteção do lago.

Ademais, não há um plano de manejo constituído para que se possa dirimir as atividades a serem desenvolvidas no entorno do lago, o que incinde no alto índice de denúncias contra invasão, queimadas, desmatamento, assoreamento, poluição e contaminação da água e solo, por parte dos moradores da Comunidade do Juá, dos pescadores artesanais do lago e sociedade civil ao poder público municipal.

Assim, esta pesquisa mostra caminhos para que o poder público e a sociedade possam agir em prol da conservação ambiental desta área, visando ainda a melhoria da qualidade de vida das pessoas que vivem nela ou que a utilizam para seu sustento, como é o caso dos pescadores artesanais que exercem a pesca tradicional no lago.

Participação dos autores: MCC - concepção do projeto e do artigo, captação de recurso, coleta e análise dos dados. Os dados foram parte da dissertação de mestrado de MCC; HSA - concepção do projeto e do artigo, análise dos dados, redação e revisão do texto, captação de recurso e coordenação do projeto; TAV - redação e revisão do texto.

Aprovação ética e outras licenças: trabalho aprovado pelo Comitê de Ética em Pesquisa (CEP), da Universidade do Estado do Pará (UEPA) - Campus XII - Tapajós, sendo aprovada pelo parecer nº 2.447.030, em 19/12/2017. 
Disponibilidade dos dados: Acervo das Bibliotecas da Ufopa. Disponível em: https://sigaa.ufopa.edu.br/sigaa/public/ biblioteca/buscaPublicaAcervo.jsf\#. Número de Registro no Sistema: 20663. Número de Chamada: 304.23 C268t DISS. Apenas versão digital na biblioteca da Ufopa.

Fomento: Bolsa Capes de Mestrado; CAPES Procad Amazônia 1778/2018.

Conflito de Interesses: os autores declaram que não há conflitos de interesse.

\section{Referências}

Acselrad H. (Org). 2004. Conflitos Ambientais no Brasil. Rio de Janeiro: Relume Dumará - Fund. Heinrich Boll. 296p.

Acypreste IP. 2015. Mulheres pescadoras: as tramas e os dramas do trabalho feminino na pesca. Revista Intercâmbio, 6:52-70

Alberti V. 2000. Indivíduo e biografia na história oral. Rio de Janeiro: CPDOC. $5 f$.

Almeida AWB. 1996. Refugiados do desenvolvimento: os deslocamentos compulsórios de índios e camponeses e a ideologia da modernização. Travessia, 20(25):30-35.

Almeida AWB. 2004. Terras tradicionalmente ocupadas: processos de territorialização e movimentos sociais. RBEUR, 6(1):9-32. DOI: https://doi.org/10.22296/2317-1529.2004v6n1p9

Almeida AWB. 2008. Conhecimento tradicional e biodiversidade: normas vigentes e propostas. Manaus: Programa de Pós-Graduação da Universidade Estadual do Amazonas / Programa de Pós-Graduação em Sociedade e Cultura da Amazônia / Fundação Ford / Fundação Universidade do Amazonas, v. I. (Coleção Documentos de Bolso, 4).

Almeida AWB (Org). 2009. Conflitos sociais no “Complexo Madeira”. Manaus: UEA Edições. 292p.

Baldin N, Munhoz EMB. 2011. Educação ambiental comunitária: uma experiência com a técnica de pesquisa Snowball (Bola de Neve). Revista Eletrônica do Mestrado em educação Ambiental, 27(1):46-60.

Becker BK. 2009. Amazônia: geopolítica na virada do III milênio. Rio de Janeiro: Garamond. 172p.

Borcem ER, Furtado Junior I, Almeida IC, Palheta MKS, Pinto IA. 2011. A atividade pesqueira no município de Marapanim-Pará, Brasil. Revista de Ciências Agrárias, 54 (3):189-201. DOI: https://doi.org/10.4322/rca.2012.014

Cardoso MC, Silva RE, Silva ADB, Alves-Chiba HS. 2018. Pescadores artesanais, conflito de interesses e os recursos pesqueiros vistos como capital natural crítico: o caso do Lago do Juá em Santarém, Pará. O Social em Questão [online], 21(40):309-332.

Cardoso MC, Souza RR, Alves-Chiba HS, Vieira TA. 2017. Expansão urbana em Santarém, Pará: uma análise a partir da ocupação Vista Alegre do Juá. In Anais do VIII Seminário Internacional sobre Desenvolvimento Regional, Universidade de Santa Cruz do Sul, Rio Grande do Sul.

Chaves MPS, Barros JF, Fabré NN. 2008. Conflitos socioambientais e identidades políticas na Amazônia. Achegas.net, 37:42-57.

Coelho YKS, Imbiriba LC, Serrão EM, Zacardi DM. 2020. A pesca camaroeira em Santarém, Baixo Amazonas, Pará. Gaia Scientia, 14(1):166-178. DOI: https://doi.org/10.22478/ufpb.1981-1268.2020v14n1.50238

Corrêa JMS, Rocha MS, Santos AA, Serrão EM, Zacardi DM. 2018. Caracterização da pesca artesanal no Lago do Juá, Santarém, Pará. Revista Agrogeoambiental, 10(2):61-74. DOI: http://dx.doi.org/10.18406/2316-1817v10n220181116

Cunha LH. 2004. Da Tragédia dos Comuns à Ecologia Política: Perspectivas analíticas para o manejo comunitário dos recursos naturais. Raízes, 23(1):10-26. 
Darwich AJ, Aprile FM, Robertson BA, Alves LF. 2005. Limnologia do Lago Tupé: dinâmica espaço-temporal do oxigênio dissolvido. In Santos-Silva, EN et al. Biotupé: Meio Físico, Diversidade Biológica e Sociocultural do Baixo Rio Negro, Amazônia Central. Manaus: Editora. p. 35-67.

Di Ciommo RC. 2018. Pescadoras e pescadores: a questão da equidade de gênero em uma reserva extrativista marinha. Ambiente e Sociedade, 10(1):151-163. DOI: https://doi.org/10.1590/S1414-753X2007000100010

Embrapa. Empresa Brasileira de Pesquisa Agropecuária. 2006. Recuperado de https://www.embrapa.br/

Fearnside PM. 2005. O cultivo da soja como ameaça para o meio ambiente na Amazônia Brasileira. In: Vieira I; Forline L; Murrieta I (Orgs.). Amazônia além dos 500 anos. Belém: Museu Paraense Emílio Goeldi, p. 281-324.

Fernandes TP, Ximenes LC. 2020. Comportamento de Ficus na arborização urbana do bairro Santa Clara, Santarém/ Pará. Revista Ibero Americana de Ciências Ambientais, 11(1):29-39. DOI: http://doi.org/10.6008/CBPC21796858.2020.001.0004

Franco EC, Santo CE, Arakawa AM, Xaxier A, França ML, Oliveira NA, Machado MAMP, Bastos RS, Bastos JRM, Caldana ML. 2015. Promoção da saúde da população ribeirinha da região amazônica: relato de experiência. Revista CEFAC, 17(5):1521-1530. DOI: http://dx.doi.org/10.1590/1982-0216201517518714

Fraxe TJP. 2004. Cultura Cabocla-ribeirinha. São Paulo: Annablume. 374p.

Gil AC. 2008. Métodos e Técnicas de Pesquisa Social (6 ed.). São Paulo: Atlas. 200p.

Jara O. 2012. A sistematização de experiências: prática e teoria para outros mundos possíveis. Brasília: CONTAG, 332p.

Leopoldo NCM, Costa TGA, Iwata BF, Toledo CE. 2020. Vulnerabilidade ambiental do Parque Nacional das Nascentes do Rio Parnaíba - PNNRP. Gaia Scientia, 14(1):33-42. DOI: https://doi.org/10.22478/ufpb.1981-1268.2020v14n1.46029

Little PE. 2004. Territórios sociais e povos tradicionais no Brasil: por uma antropologia da territorialidade. Anuário Antropológico, 28(1):251-290.

Lui GH, Molina SMG. 2009. Ocupação humana e transformação das paisagens na Amazônia brasileira. Amazônica Revista de Antropologia, 1(1):200-228.

Maneschy MC, Alencar E, Nascimento IH. 1995. Pescadoras em busca de cidadania. In: Álvares MLM, D'Incao MA. A mulher existe? Uma contribuição ao estudo da mulher e gênero na Amazônia. Belém: GEPEM, p. 81 - 96.

Oliveira RQ, Carleial LMF. 2013. Desenvolvimento Amazônico: uma discussão das políticas públicas do Estado Brasileiro. Refaf, 2(1):1-32.

Pádua EMM. 2012. Metodologia da pesquisa: abordagem teórico prática. (17ed.) Campinas: Papirus. 97 p.

Penroid J, Preston DB, Cain R, Starks MT. 2003. A discussion of chain referral as a method of sampling hard-to-reach populations. Journal of Transcultural Nursing, 4(2):100-107.

Prates RC, Bacha CJC. 2011. Os processos de desenvolvimento e desmatamento da Amazônia. Economia e Sociedade, 20(3):601-636. DOI: https://doi.org/10.1590/S0104-06182011000300006

Rapozo PH. 2015. Territórios sociais de pesca no Rio Solimões: usos e formas de apropriação comum dos recursos pesqueiros em áreas de livre acesso. Manaus: EDUA. 214p.

Ribeiro Filho MJ. 2012. Paisagem e impactos socioambientais do Lago do Aleixo: um estudo sobre a percepção dos moradores do entorno (Dissertação de mestrado). Universidade Federal do Amazonas, Manaus, AM, Brasil. 96p.

Rocha EJP, Souza EB, Santos FAA, Lopes MN, Santos DM, Rolim PAM, Simões Neto B, Maia IF. 2009. Zoneamento climático: relatório preliminar - ZEE-PA. Belém: SIPAM. 
Santos MAS, Guerreiro Filho MCS, Neves PR, Aguiar CGG. 2005. Análise socioeconômica da pesca artesanal no Nordeste Paraense. In Anais do XLIII Congresso da Sober: Instituições, Eficiência, Gestão e Contratos no Sistema Agroindustrial, Sociedade Brasileira de Economia, Administração e Sociologia Rural, Ribeirão Preto.

Sepof. Secretaria Estadual de Planejamento Orçamento e Finanças. 2006. Anuário estatístico do Estado do Pará. Recuperado de https://www.seplan.pa.gov.br/

Silva JT, Braga TMP. 2016. Caracterização da pesca na comunidade de Surucuá (Resex Tapajós Arapiuns). Biota Amazônia, 6 (3):55-62.

Silva TV, Machado CSM, Zagui GS, Machado GP, Micas AFD, Savazzi EA, Segura-Muñoz SI. 2020. Avaliação toxicológica de ambientes aquáticos. Gaia Scientia, 14(1): 63-73. DOI: https://doi.org/10.22478/ufpb.1981-1268.2020v14n1.50281

Soares Filho BS, Dietzsch L, Moutinho P, Falieri A, Rodrigues H, Pinto E, Maretti CC, Suassuna K, Scaramuzza CAM, Araújo, FV. 2008. Redução de emissões de carbono associadas ao desmatamento no Brasil: o papel do Programa Áreas Protegidas da Amazônia (Arpa). IPAM, Brasília. 32p.

Sousa WL, Monte LFO, Silva RE, Vieira TA. (2018). Protagonismo socioeconômico das pescadoras artesanais do bairro Pérola do Maicá, em Santarém Pará. Revista Ciências da Sociedade, 2 (4):143-161. DOI: https://doi.org/10.30810/rcs. v2i4.907

Suemitsu C, Novais JS, Vargas JT. 2013. Notas florísticas sobre o entorno do Lago do Juá, margem direita do Rio Tapajós, Baixo Amazonas, Pará. In Anais do 64 Congresso Nacional de Botânica, Sociedade Botânica do Brasil, Belo Horizonte, MG, Brasil.

Torres JR, Gehlen, S, Muenchen, C, Gonçalves FP, Lindemann RH, Gonçalves FJF. 2008. Ressignificação Curricular: contribuições da Investigação Temática e da Análise Textual Discursiva. Revista Brasileira de Pesquisa em Educação em Ciências, 8(2):1-13.

Trindade Júnior SCC. 2015. Pensando a modernização do território e a urbanização difusa na Amazônia. Mercator Revista de Geografia UFC, 14(4):93-106. DOI: https://doi.org/10.4215/RM2015.1404. 0007

Turner M. 2004. Political Ecology and the Moral Dimensions of "Resource Conflicts": The case of farmer-herder conflicts in the Sahel. Political Geography, 23(7):863-889. DOI: https://doi.org/10.1016/j.polgeo.2004.05.009

Valencio NFLS, Venturato RD. 2009. Desafios do Modo de Vida da Pesca Artesanal em uma Região em Crescimento: A Comunidade de Tanquã, Piracicaba/SP. Boletim do Instituto de Pesca, 2(35):318-333.

Vaz EM, Rabelo YGS, Corrêa JMS, Zacardi DM. 2017. A pesca artesanal no lago do Maicá: aspectos socioeconômicos e estrutura operacional. Biota Amazônia, 7(4):6-12. http://dx.doi.org/10.18561/2179-5746/biotaamazonia.v7n4p6-12

Zacardi DM, Ponte SCS, Silva AJS. 2014. Caracterização da pesca e perfil dos pescadores artesanais de uma comunidade às margens do rio Tapajós, Pará. Amazônia: Ciência \& Desenvolvimento, 10(19):129-148. 